\title{
Osmanlı Devletinde Tütün Ticareti: Aslıoğlu Serahim'e Ait Adana Tütü̈n Fabrikası Örneği
}

\author{
Tobacco Trade In The Ottoman State: Example Of Adana Tobacco Factory Owned \\ By Aslioğlu Serahim
}

Sezgin $Z A B U N^{*}$

$\ddot{O} Z$

Tütün dünyaya Amerika'dan yayıldı. Bu nedenle Amerika dışındaki dünyada geçmişi 500 yıl kadardır. Amerikan yerlileri tütünü tedavi edici olarak ve dini ayinlerde kullanmışlardır. Tütün coğrafi keşiflerden sonra İspanya aracılı̆̆ıyla Avrupa'ya getirilmiştir. Avrupa'da sigara, sarmalık nargile, enfiye, çiğnemelik gibi pek çok farkl formda tüketilmiştir. Baş ăgrısı, mide hastalıkları, kadın hastalıkları gibi pek çok hastalığı da iyi geldiği iddia edilmiştir. Günümüzde pek çok hastalığın, özellikle de kanser hastalıklarının sebebi olarak kabul edilse de alışkanlık yapma özelliği nedeniyle pek çok kişi istediği halde vazgeçememektedir.

1500'lü yılların başında Avrupa'ya gelen tütün, kısa süre sonra denizciler aracıllğıyla Osmanlıya ulaştı. Tedavi edici olduğu kanaati ile birlikte alışkanlık yapma özelliği tütünü kısa zamanda önemli bir sanayi bitkisi yaptı. Osmanlı'dan alacaklarını tahsil etmeye gelen Düyun- u Umumiye ve bu çerçevede kurulan ve 10 yıllık Tekel elde eden çok uluslu Reji Şirketi, tütün üretimini, tüketimini ve ticaretini kontrol etmiştir. Adana Külahçılar da Tütün Fabrikası da bu çerçevede tütün mamülleri üretimi ve ticareti yapmıştır. Bu çalışmada Adana Külahçılarda bulunan tütün fabrikasının Aslıoğlu Serahim Efendiye devir teslimine ait Osmanl arşiv belgesi esas alınarak söz konusu fabrikayla ilgili ekonomik veriler ortaya konulmuştur.

ANAHTAR KELIMELER

Osmanlı, Tütün, Adana, Külahçılar Çarşısı

\begin{abstract}
Tobacco spread to the world from America. Therefore, it has a lifespan of 500 years in the world outside of America. Native Americans also used tobacco in therapeutic and religious rituals. After geographical discoveries, tobacco came to Europe via Spain was consumed in many different forms (cigarette, coiled tobacco, pipe, cigar, hookah tobacco, snuff, chewing tobacco). It has also been suitable for many diseases (cough, asthma, headache, stomach ailments, gynecological diseases, etc.). Although it is accepted as the cause of many diseases, especially cancer, many people cannot give up even if they want to because of its habit-making feature.

Arriving in Europe in the early 1500s, tobacco soon reached the Ottoman Empire through sailors. With the belief that it is therapeutic, its habit-forming feature made tobacco an essential industrial plant quickly. The Duyunu Umumiye, which came to collect its receivables from the Ottoman Empire and the multinational Reji Company, established within this framework and achieved a 10-year Monopoly, controlled tobacco production, consumption and trade. Both Adana Külahçlar and Tobacco Factory were engaged in producing and trading tobacco products within this framework. In this study, it is tried to present the economic data about the tobacco factory in Adana Külahçlar that was handed over to Aslioğlu Serahim Efendi.
\end{abstract}

\section{KEYWORDS}

Ottoman, Tobacco, Adana, Külahçılar Bazaar

\begin{tabular}{|c|c|c|}
\hline \multicolumn{2}{|r|}{$\begin{array}{c}\text { Makale Geliş Tarihi / Submission Date } \\
\text { 14.09.2021 }\end{array}$} & $\begin{array}{c}\text { Makale Kabul Tarihi / Date of Acceptance } \\
\text { 22.11.2021 }\end{array}$ \\
\hline Atıf & $\begin{array}{l}\text { Zabun, S. (2021). Osmanlı Devletinde } \\
\text { Üniversitesi Sosyal Bilimler Meslek Yi }\end{array}$ & $\begin{array}{l}\text { Serahim'e Ait Adana Tütün Fabrikası Örneği. Selçuk } \\
\text { 2), 622-634. }\end{array}$ \\
\hline
\end{tabular}

\footnotetext{
* Dr. Öğr. Üyesi, Sivas Cumhuriyet Üniversitesi İktisadi ve İdari Bilimler Fakültesi, sezginzabun@ cumhuriyet.edu.tr, ORCID: 0000-0003-2566-2513
} 


\section{GİRIŞ}

Amerika kıtasının 1492'de keşfinden sonra Amerika'dan Avrupa'ya getirilen tütün, daha sonra dünyaya yayıldı. Gemiciler vasıtasıyla Akdeniz üzerinden Osmanlı topraklarına girdi. Devletin kayıtlarında duhân, halk tarafından tütün diye isimlendirildi. Ticaretini yapanlar ilaç olduğunu öne çıkararak pazarlamasını yaptı. Kısa sürede oldukça yaygın tüketilmeye başlandı.

Müslüman ülkeler tütüne şüpheyle yaklaştı. Kimilerine göre haram, kimilerine göre mekruhtu. Sonunda yasaklanması fermanı geldi. Yasak sonucunda tütün üretimi ve tüketimi gözden 1rak oldu. Buna bağlı olarak tütün ekim alanlarının vasfi ve yeri değişti. Erişimin dolayısıyla kontrolün zor olduğu bölgeler ve yerler kaçak üretim ve kaçak tütün ticareti yapmaya başladı. Daha sonra yasakların kalkmasıyla üretim yeniden ovalara indi.

Çiftçiler açısından karlı bir sanayi bitkisi olan tütün, yarattığı istihdam ve gördüğü taleple çok geçmeden ülkenin verimli topraklarında yetiştirilmeye başlandı. Özellikle Ege Bölgesi, Marmara, Trakya, Balkanlar, Çukurova ve Suriye 'de başlatılan tütün üretimi zamanla ekili alan miktarını artırdı. Bu artışta artan talep ve yüksek oranda kar getirisi rol oynamıştır. Ege Bölgesi'nde belirlenmiş alanlarda belirlenmiş kişiler eliyle ilk ticarî tütün üretimi 1583 'te başladı. "Tütün ekim alanlarını tespit eden 1691 tarihli tahrire göre imparatorlukta toplam kırk bir kazanın 819 köyünde 10.273 çiftçi, 10.177 dönüm alanda tütün ekmekteydi” (Yılmaz, 2012: 2).

Osmanlı topraklarında başlangıçta Avrupalı tüccarların getirdiği mamul tütün ürünlerinin ticareti yapılmaktaydı. Ancak zamanla hem üretimi, hem tüketimi yaygın hale geldi. Bu yeni duruma bağlı olarak profesyonel tüccarlar ortaya çıktı. XVIII. yüzyılın ortalarından itibaren Ege, Tuna sahilleri ve merkezden uzak bölgelerdeki âyanlar tütün ticaretinde etkin hale gelirken yerli gayri Müslim tütün tüccarının sayısı da artmaya başladı. Fakat hiçbir vakit sayıca çoğunluğu oluşturmadı. 'İstanbul Tütün Gümrüğü verilerine göre 1697'de İstanbul'a tütün getiren tüccar sayıs1 172 olup bunların \% 94'ü Müslüman, \% 6's1 gayri Müslim; 1817'de tüccar sayıs1 954 olup \% 57'si Müslüman, \% 43'ü gayri Müslim'di. Selânik'te 1697'de 57 tüccarın \% 95'i Müslümanlardan, \% 5'i gayri Müslimlerden meydana geliyordu. 1773'te Selânik'te 235 tütün tüccarından \% 80'i Müslüman, \% 20'si gayri Müslim'di” (Y1lmaz, 2012: 3).

Reji İdaresi'nin kurulacağını ve tütün üretim ve ticaretinin bu idare tarafından kontrol edileceği bilgisini alan Osmanlı çitçisinin bu duruma pek hoşnut olmadıkları görülmektedir. Nitekim bir grup Osmanlı çiftçisinin aşağıdaki telgrafı bunun somut bir göstergesidir. İlgili telgrafta tütünde reji idaresinin faidesinin olmayacağı ancak zararının olacağına dikkat çekilmiştir. Reji şirketinin kurulacağına dair bilgi sahibi olan Osmanlı çiftçisinden bir grup, gerekli uyarıları yapan aşağıdaki telgrafı çekmişlerdir. "Reji denilen şey icra olunup bir sene içinde tırnaklarımızı dökercesine emek vererek ve tekmil vaziyetimizi sarf eyleyerek husule getirdiğimiz tütünlerin ele verilişi, bir kumpanyanın eline verilecekmiş, artık bundan bir güne hayır mamul etmek bizim için haram olup zaten kazamızın bir duhan mahsulü vardır ki biraz yüzümüzü güldürür ve vyal ve evlatlarımızın idare veya iaşesine elverir. Bu suretle ecnebi eline geçince esiri olacağımız ve nihayetinde Frengistan'a götürülmekte olan duhanın ticaretini dahi onlara kaptırıp bundan bütün bütün açıkta kalacağımız meydandadır Zira şimdiye kadar bunların bir işi kolay girip çıktıkları görülmemiştir. Elbette sonunda faidesi müşahade olmayıp zararı görülür" (COA. Y. PRK: AZJ.6-60).

Bu telgraf Kavala'dan çekilmiştir. Altında sırasıyla; Uzunkapu, Buzaklı, Darıova, Kuzudere, Çıplak, Ahmedli, Karacaviran, Filinkar, Deviran, Deviranlı, Çobanlı, Karacakoyun, Karacalar ve Okçular köyleri imam ve muhtarlarının imzası vardır.

Çalışmada girişi müteakiben ilk kısımda Osmanlı devletinde tütün üretimi ve ticareti hakkında bilgiler verilmiş ikinci kısmında ise Reji idaresinin tütün tekeli izahata kavuşturulmuş, son kısmında ise Adana tütün fabrikasının tütün ticaretiyle ilgili bilgiler verilmiştir. Özellikle Adana tütün fabrikasıyla ilgili literatürde herhangi bir çalışmanın bulunmayışı bu çalışmanın kıymetini artırmakta gelecekte konuyla ilgili araştırmacılara bir ışık tutma misyonu ifa edeceği düşünülmektedir. Çalışmada Osmanlı arşiv belgeleri esas alınmıştır. Bu belgeler Adana tütün fabrikasının devir teslim tutanağı, ilgili dönemde meri olan ve tütün üretimi ve ticaretini düzenleyen kanun, adı geçen kanunun bazı maddelerini yeniden düzenleyen kararname ve Reji şirketine verilen tütün imtiyazına yönelik olarak Kavalalı tütün üreticilerinin şikâyetlerini bildiren telgrafnamedir.

\section{TÜTÜNÜN OSMANLI'YA GELİŞİ}

Son 500 yıldır bütün dünyanın ve daha öncesinde Amerika yerlilerinin tükettiği tütünün zararlı olduğu artık genel bir kanaattir. Pek çok ülke tütün tüketimini sınırlamak ya da yasaklamaktadır. Ayrıca tütün tüketimini engelleyici kısıtlayıcı yasal tedbirler almaktadır. Tüm tedbirlere rağmen, bağımlılık yaratıcı etkisi nedeniyle tütün tüketimi dolayısıyla üretimi süregelmektedir. "Tütünün ticari açıdan yararlanılan en önemli kısmı olan 
yaprağı, barındırdığı kimyasal özellikleri bakımından üretiminde önem taşımaktadır. Ayrıca kökte sentezlenen ve tütün yaprağında biriken nikotin güçlü bir alkaloittir ve keyif verici, bağımlılık yapıcı özelliği bulunmaktadır" (Aydın, Kaya ve Karaçor, 2019: 20 ).

Tütün Osmanlı topraklarına Avrupalı gemiciler tarafından ilk defa getirilmiştir. Amerika'nın keşfiyle ilk önce İspanya'ya oradan tüm dünyaya yayılan tütün, Osmanlı İmparatorluğu'na 1600'lü yıllarda gelmiştir. Pek çok hastalığa iyi geldiği iddiasıyla hüsn-ü kabulü ve yüksek talebi sağlanmıştır. Osmanlı coğrafyasında tütünün hem üretimi hem de tüketimi kısa zamanda yaygın hale gelmiştir. Düyun-u umumiye alacaklarını tahsil amacıyla Çok uluslu Reji Şirketi'nin kurulması, yarattığı istihdam ve karlı oluşunun yanı sıra, gördüğü aşırı talep tütünü vazgeçilmez kıldı. Ancak devletin dış borçlarını ödemek için mahkûm olduğu Reji uygulaması Osmanlı çiftçisi için olumsuz sonuçlara yol açmıştır. Osmanlı Devleti düştüğü Borç batağı yüzünden, şirketle yaptığı ağır şartlar içeren anlaşmada verdiği imtiyazlar sebebiyle şirketin pervasız uygulamalarına ses çıkaramamıştır. "Reji Şirketi'nin kurulmasıyla en önemli gelir kaynaklarından birini kaybeden Osmanlı Devleti Reji’nin faaliyetleri üzerinde söz sahibi değildi. Tütün üreticilerine kâr marjını arttırmak adına her türlü eziyeti çektiren Reji İdaresi'nin faaliyetlerine, Osmanlı İmparatorluğu aldığı borçlardan dolayı göz yummak zorunda kalmıştır” (Aydın, Kaya ve Karaçor, 2019: 19 ).

Birçok hastalığa ilaç olmak gibi bir referansla Avrupa'ya gelen tütün, Müslüman ülkelerde ihtiyatlı karşılanmıştır. Uzun yıllar tüketiminin mübah olup olmadığı tartışması yapılmıştır. Yabancı tüccarlar tarafindan her hastalığa çare diye tanıtılan tütünün tüketiminin hızla yayılışı imparatorlukta dinî tartışmalara ve siyasal tepkilere yol açmıştır. Dinî tartışmalarda tütünün haram, mekruh veya mubah olup olmadığı, yasaklanıp yasaklanmayacağı konusu gündeme gelmiştir. Siyasî tepki ise diğer devletlerde olduğu gibi üretim, ticaret ve tüketim meseleleri üzerinde yoğunlaşmıştır (Yılmaz, 2012: 1).

20 yüzyılın başlarında sigarayı yasaklama çabaları gündeme gelmişse de 1914 yılında Birinci Dünya Savaşı'nın çıkması, tütünü yasaklama çabalarını engellemiştir. Cephede asker kumanyalarına tütün ilave edilmiş, şiddetle ihtiyaç duyulan tütünü temin etmek ve cepheye ulaştırmak gayreti ön plana çıkmış, savaşlı yılların sonunda tütün/sigara tüketimi daha da artmıştır. İkinci Dünya Savaşı ile birlikte tütün ve sigara cephede en az silah ve mühimmat kadar aranır hale gelmiş, özellikle sigara tüketimi yaygınlaşmış, dünyada yetişkin nüfusun yaklaşık yüzde 60-80'i sigara içer hale gelmiştir. 20'nci yüzyılın ortalarında hastalıklara ve ölümlere neden olduğu bilimsel olarak kanıtlanan tütünün insanoğlu ile girdiği ölüm/kalım mücadelesi günümüzde tüm şiddetiyle sürmektedir (Seydioğulları, 2009).

\section{OSMANLI DEVLETI'NDE TÜTÜN ÜRETIMI VE TİCARETİ}

Tütün Amerika'dan Avrupa'ya, Avrupa'dan Osmanlı'ya getirildi. İslam dünyasında olduğu gibi Osmanlı'da da tütünün haram, mekruh, mubah olduğuna dair fetvalar verilmiştir. Bunca yıl sonra Müslümanlar hala fetva konusunda fikir birliğine varmış değildir. Ancak tütün bir sanayi bitkisi olarak en verimli topraklarda yerini almıştır. Çiftçi için karlı bir uğraş, devlet için önemli miktarda vergi ve istihdam demektir. İnsanları kendine müptela eden tütün, büyük talep görmeye devam etmektedir.

Tütün Avrupalıların elinde önemli bir ticari meta olmuş, zamanla dünyaya pazarlanmıştır. Tütün asıl vatanı olan Amerika'dan İspanyollar tarafından Avrupa'ya getirilmiştir. Memleketimizde ise 1600 civarında görülmüss kısa zamanda ve süratle pek fazla kullanılan keyif verici bir madde haline gelmiştir. XVII. yüzyılda gerek Anadolu gerekse Rumeli topraklarında tütün yetiştirildiği şer'iye sicilleri'ndeki kayıtlardan anlaşılmaktadır (Kütükoğlu, 2013: 22 ).

Kaynaklardaki bilgilerden tütünün Osmanlı topraklarına Avrupa'dan 1600'lü yıllarda geldiği anlaşılmaktadır. "Osmanlı topraklarına getiriliş tarihini Hezârfen Hüseyin Efendi 1598, Peçuylu İbrâhim 1600, Kâtib Çelebi 1601, Naîmâ 1606 olarak kaydeder. Mısırlı âlim İbrâhim el-Lekānî ise tütünün XVII. yüzyılın sonlarında ortaya çıktığını ve Anadolu'ya "Cil" adlı bir İngiliz tarafından getirildiğini belirtir. Hâlbuki söz konusu tarihler tütünün ilk ithal tarihi değil özellikle İstanbul'a yoğun biçimde getirilmeye başlandığı yılları gösterir. İlk getiriliş tarihi ise en geç 1570'ler olmalıdır( Yılmaz, 2012: 1).

Tütün kısa zamanda Osmanlı Devleti için önemli bir gelir kaynağı olmuştur. Tütünün pek çok hastalığı tedavi edici olduğu bilgisi de yaygın kullanılmasında etkili olmuş olabilir. Ege Bölgesi'nin uygun iklim koşulları nedeniyle orijini Amerika olan tütün Osmanlı'da üretilip Avrupalıların tütün talebini karşılar hale gelmiştir. "Artan tütün talebi ve Anadolu'nun tütün üretimi için gerekli iklim koşullarını sağlaması nedeniyle artan tütün üretimi hem Osmanlı İmparatorluğu'nun ekonomisi açısından hem de yarattığı yeni iş imkânları bakımından Osmanlı'ya olumlu yönde katkıda bulunmuştur" (Aydın, Kaya ve Karaçor, 2019: 20 ). Tütün tüketimine olan aşırı talep, tütün ticaretini karlı, cazip bir alan kılmıştır. Ayrıca kapitülasyonların halen yürürlükte olması, Osmanlı coğrafyasının Batılı tütün tüccarları için cazip bir pazar olmasına neden olmuştur. 17. yy. boyunca hızlı bir şekilde yayılan ve toplu tüketim maddesi haline gelen tütün, sadece imparatorluk

Selçuk Üniversitesi Sosyal Bilimler Meslek Yüksekokulu Dergisi, Yıl: 2021 Cilt: 24 Sayı:2 
dahilinde ticareti yapılan bir madde olmayıp, ülke dışında Akdeniz dünyasına ve Avrupa'ya da ihraç edilen önemli bir ihraç ürünü haline gelmiştir (Yılmaz, 2005: 53). XVIII. yüzyılın ortalarından itibaren yabancı tüccar arasına Basra ve Bağdat bölgesinden tömbeki getiren İranlı tüccarlar da katılmıştır. 1793'ten itibaren Avusturyalı tüccarlarla Rus tüccarları Karadeniz'de, İngiliz tüccarları Bağdat-Halep-Şam güzergâhında tömbeki ticaretine girişmişler, ayrıca Amerikan tütününü Mısır'a ithal etmeye başlamışlardır (Yılmaz, 2012: 3). 1609-1649 yılları arasında tütünün yasaklanmasına rağmen, kullanımının yayılıp tüketiminin artması, var olan talebe yasal olmayan yollardan cevap veren, sadece tütün ticaretiyle uğraşan profesyonel tüccar grubunun oluşmasına imkan vermiştir (Yılmaz, 2005: 54). Zararlarının anlaşılması sonrası Osmanlı İmparatorluğu'nda zaman zaman padişahlar tarafından tütün kullanımına kısıtlamalar getirilse de, üretimi dalgalanmalar gösterse de yarattığı gelir nedeniyle tütün üretimi günümüze kadar devam ettirilmiştir.

Tütün üretimi ve tütün mamulleri imalatı önemli düzeyde istihdama neden olmuştur. Aynı zamanda Osmanlı hazinesi için de önemli vergi kalemlerinden biri haline gelmiştir. Osmanlı Devleti tütünün topraklarına getirilmesinden itibaren tütün ziraatıyla ilgilenmiş ve tütün üretiminde çalışan işçilere, tüccarlara ve aracılara iş kapısı açmıştır. İstihdam yaratması dışında imparatorluk için de tütün vergisi önemli bir gelir kaynağı olmuştur. Tütünün işlenmesi ve sigara imalatı büyük sayıda işçinin istihdamına yol açmıştır. “İstanbul'daki tütün inhisarında 1875'te 70 memur ve çoğu kadın 1402 çalışıyordu. Cibali' deki tütün fabrikası 1600 kişi istihdam ediyordu. Bunların arasında 180 erkek işçi tütün nevilerini ayırıyor ve 100 erkek veya kadın işçi tütün yapraklarını kesiyordu. Gerisinin çoğu paket eden ve sigara satan kadın işçilerdi”" (İnalcık, 1997: 1014).

Osmanlı Devleti tütün ithalatı, ihracatı ve üretimi konusunda yasal düzenlemeler yapmış, yasaya aykırı davrananlara gerekli cezaları belirlemiştir. Ecnebi tütün mamulatının ithali hakkında ki kanunun ithalat resmini düzenleyen 31 maddesine göre: "Ecnebiye den gelen kıyılmış tütünün beher kilosundan bir lira, sigaranın kilosundan 1 buçuk lira ithalat resmi" alınırdı. Yine kanunun aynı maddesine göre, "yaprak sigaralardan ve ağız tütünü ithalatından değerinin yüzde yetmiş oranında ithalat resmi, enfiyeden ise kıymetinin yüzde yüzü olanında ithalat resmi” tahsil edilirdi (COA.İ..DUİT_97-1_11_54_01).

Mezkur kanunun 46 maddesinde tütün kaçakçıllı̆̆ konusunda da düzenlemeye gidildiği ve "Kaçak tütün bulunduranların tütünleri müsadere edilir kilo başına da 1 Osmanlı altını ceza-i nakdi tahsil olunur" ( İ.DUİT_97-1_11_54_01) hükümlerinin yer aldığ1 görülmektedir. Kanunun 47 maddesi kaçak imalat yapanlarla ilgilidir. Kaçak imalatta kullanılan alet ve edevatın müsadere edileceği ve müsadere edilen her bir alet için 15 liradan 25 liraya kadar vergi cezası kesileceği aynı zamanda ilgili suçu işleyenlere hapis cezası da verileceği belirtilmektedir ( İ..DUITT_97-1_11_54_01). 49 maddeye göre ise" tütün kaçakçılığı cürmü ile mahkûm olanlar aldıkları cezanın yanı sıra 50 adet Osmanlı altını vermeye mahkûm olur" ( İ..DUİT_971_11_54_01).

27 Rebiül ahir 1340 (M.1922) tarihli kararnamede ise vergi miktar ve oranları değiştirilmiş, kıyılmış tütünün her kilosundan 6 lira, sigaraların 1000 adedinden 15 lira ithalat resmi alınması kararlaştırılmıştır (COA. İ..DUIT_00091686.380).

Osmanlı İmparatorluğu savaşlar sebebiyle kaynak arayışında idi. Gerekli kaynak yeni vergilerle bulundu. Yeni ihdas edilen bu vergilerden biri de "duhan resmi" adıyla maruf tütünden alınan gümrük vergisiydi. 1683 'te İkinci Viyana bozgununun ardından devam eden savaşlar yüzünden maliyeye ek kaynak sağlamak için ilk defa Ağustos 1688'de devletçe "duhan resmi” adıyla tütün gümrük vergisi kondu. Vergi İsakça' dan Çanakkale'ye kadar Rumeli ile Hudâvendigâr bölgelerini kapsıyordu. Bu sınırlar, tütün gümrük vergisinin Nisan 1689 'da alkollü içki vergisiyle birlikte "hamr ü arak ve resm-i duhân" adıyla mukātaa haline getirilmesinden sonra da değişmedi (Yılmaz, 2012: 4).

Osmanlı Devleti borçlanmaya gitmeden önce iç kaynaklara yöneldi. Mevcut vergilerin etkinliğini artırırken yeni vergilerde uygulamaya koydu. Yeni vergilerle birlikte toplumun vergi yükünde de artış yaşandı. Osmanlı ekonomisi üzerindeki vergi yükünü ağırlaştıran bir diğer gelişme de, "18. yüzyılın ilk çeyreğinden itibaren ihracatı hızla artmaya başlayan tütün, pamuk, pamuk ipliği, zeytinyağı, balmumu buğday gibi mallarda tarifedeki normal gümrük vergisinden ayrı olarak "resm-i miri" adı ile başlangıçta sadece ihracattan alınmak üzere vaz edilen tek verginin, 1760'lardan itibaren iç ticari mübadeleye teşmil edilmiş olmasıdır" (Genç, 2000: 203).

Osmanlı Devleti ilk defa Kırım harbi nedeni ile borç almıştı. 1854'te ki bu ilk borçlanmayı yeni borçlanmalar takip etti. İlk borçlanmadan 20 yıl sonra borçlarını ödeyemez duruma düşmüştü. Borçların ödenmesi için düyun-u Umumiye kuruldu. Bu çerçevede kurulan çok uluslu reji şirketi de monopol imtiyazları ile donatılmış idi. "Osmanlı Devleti, 1883 yılında yabancı sermaye ile kurulacak olan Tütün Rejisi şirketine İmparatorluk içindeki tütün üretiminin denetlenmesinde, tütün alım ve satımında ve sigara üretiminde tekelci 
ayrıcalıklar tanımaktaydı. Reji şirketinin yıllık karlarının bir bölümü dış borç ödemelerinde kullanılmak üzere Düyunu Umumiye idaresine aktarılacaktı" (Pamuk, 2014: 122 ).

Osmanlı Devleti Reji Şirketi'nin haksız uygulamalarını, yapılan anlaşmalar münasebetiyle sineye çekmek zorunda kalmıştır. Reji uygulamasıyla birlikte tütün kaçakçılığı da artmaya başlamıştır. Tütün üretimi ve vergilendirilmesi alanında her türlü yetkinin ve sorumluluğun Reji Şirketi'ne devriyle Osmanlı İmparatorluğu'nun vergilendirme sisteminde köklü bir değiş̧ikliğe gidilmiştir. Reji tütünün üretimi ve fiyatlandırmasını kendi tekeli doğrultusunda yaptığından genellikle düşük fiyat vermekte, çiftçiyi kaçakçıllığa sevk etmekteydi. Daha önce olmadığı kadar kaçakçılık faaliyetleri gelişmiş, hayatını idame ettirmek isteyen çiftçi için bir zorunluluk haline gelmişti. Reji'nin kaçakçılıkla mücadele için oluşturduğu kolluk adı verilen güvenlik güçleri genellikle sorunlu insanlardan meydana getirilmekle beraber halkı bask1 ve zulümle düzene getirmeye çalışıyorlardı. Kaçakçılık mücadelesi uğruna halkı öldürmekten çekinmiyor genellikle silahlı müdahalelerde bulunuyorlardı (Aydın, Kaya ve Karaçor, 2019: 26).

Tütün üretim ve ticaretinin yaygınlaşması zamanla tütüncü esnafının örgütlenmesini getirdi. Örgütlenen tütüncü esnafı Osmanlı esnaf teşkilatı içinde yerini aldı. Gedikli esnafın yanında, sokak aralarında yasadışı tütün ticareti yapan bir kesim de ortaya çıktı. "1696'da İstanbul'da 366 tütüncü esnafı olup Sur içi, Galata, Tophane, Eyüp ve Üsküdar'da faaliyet göstermekteydi. Bunlar 1726'da lonca teşkilâtlarını kurdular. 1782'de sayıları 1709'a ulaştı ve tütüncü esnafı loncasının isteğiyle gedik uygulaması başlatıldı. Buna rağmen 1831'de sayıları 1744'e ulaştı. Gedik sahibi olanlar dışında kefilsiz kıyıcı denilen ve izinsiz şekilde sokak aralarında terbiyeli tütün diye adlandırılan, içine toprak ve yaprak karıştııılmış hileli tütün satan kişiler ortaya çıktı. XVII. yüzyılda tütüncü esnafının \% 99'u Müslüman, \% 1'i Yahudi iken XIX. yüzyılın ortalarında \% 65'i Müslüman, \% 30'u Hristiyan ve \% 5'i Yahudilerden oluşuyordu" (Y1lmaz, 2012: 4).

Osmanlı coğrafyasında Anadolu ve Rumeli'deki verimli topraklarda tütün yetiştiriliyordu. Tütün üretim miktarları ve tütün ihracatı giderek artıyordu. "1907 rakamlarına göre Rumeli'de tütün ekili alanlar 270 bin dönüm, toplam ürün 22 bin ton, ederi 125 milyon guruștur. Anadolu'da ise 460 bin dönümden 24 bin ton ürün alınmış ederi ise 120 milyon guruştur" ( Güran, 1998: 76 ). "1689'da Selânik'ten Avrupa'ya yapılan üç aylık tütün ihracat1 92.477 okka idi. Bu miktar 1722'de 717.728 okkaya, 1736'da 1.143 .100 okkaya yükseldi. 17561764 yıllarında 2 milyon okkaya çıktı" (Yılmaz, 2012: 3). 18. yy.'ın ikinci yarısında tütün ihracatı, bazı yıllardaki istisnalar hariç, ortalama olarak 1.000.000 okkanın üzerinde seyretmiştir (Yılmaz, 2005: 73).

Osmanlı Devleti çeşitli nedenlerle zaman zaman tütüne yasaklarda getirmiştir. Bazen bir yangın, bazen bir fetva getirilen yasakların sebebi oldu. Yasaklar IV. Murad döneminde daha da sıkı hale geldi. 1633'te İstanbul'da büyük tahribata yol açan yangının sebebi tütün olarak gösterilince kontroller arttırıldı. 1640'ta IV. Murad'ın ölümünün ardından yasağın etkisi azaldı (Yılmaz, 2012: 1).

Osmanlı coğrafyasında tütün üretimi ve ticareti, Reji şirketinin kontrolü altındaydı. Tütün üretimi ve ticareti karlı bir iş olsa bile Reji şirketinin uygulamaları nedeniyle ne Osmanlı Devleti ne de Osmanlı çiftçisi beklenen faydayı sağlayamamıştır. Tütün Osmanlı hazinesi için önemli bir gelir kaynağı olmasına rağmen borçlara mahsup edildiğinden Devlet bu kaynaktan yeterince yararlanamıyordu. Tütün Osmanlı devletinin en önemli gelir kaynağ 1 olması nedeniyle Duyun-1 Umumiye İdaresi bu geliri doğrudan yönetmek istemiş ve bu doğrultuda 1884 senesinde Reji Şirketi'ni kurmuştur. Bu şirket Duyun-1 Umumiye İdaresi ve Osmanlı devleti, yabancı şirketler tarafından kurulan bir şirkettir. Şirketin kurulmasıyla ülkede bandrol sisteminin uyguladığ 1 tüm bölgelerde tütün ekimi, ticareti ve imali bu şirkete devredilmiş ve bu şirketin izni olmadan ülkede tütün ekimi yasaklanmıştır (Demir, 2019: 421).

\section{REJİ İDARESİ}

İlk defa 1854'te borçlanan Osmanlı Devleti 20 yıl sonra, borç taksitlerini değil, faizini dahi ödeyemez duruma düşmüştü. Borçların ödenmesini düzenlemek üzere Düyun-u Umumiye Konseyi kuruldu. "İlk borçlanmadan sonra ikinci, üçüncü, dördüncü borçlanmalar olmuş, 25 y1l içinde günden güne artan devlet borçlarının tutarı 1880'lerde 800 milyon Sterline çıkmıştır. Devlet borçlarının faizlerinin ödemeyerek, alacakların belirli İmparatorluk gelirlerinin yönetimini ele almalarına izin vermek zorunda kalmıştır. Genel borçlar yönetimi dediğimiz "Düyun-u Umumiye" örgütü kurulmuş ve gelir kaynakları üzerindeki denetimini yıldan yıla artırarak sürdürmüştür" (Çadırc1, 1997: 180). Monopol gücü ile tahkim edilen çok uluslu Reji Şirketi bu dönemde kuruldu. 1893 yılında yabancı sermaye ile kurulan Tütün Rejisi Şirketi'ne ülke içindeki tütün üretiminin denetlenmesinde, tütün alım ve satımında ve sigara üretiminde ayrıcalıklar tanındı (Akgündüz ve Öztürk, 2000: 495 ). Reji Osmanlı'dan kopardığı imtiyazlarla tütünün üretilmesinden tüketilmesine kadar bütün aşamalarını kontrol ediyordu. Reji, Osmanlı devletinde daha önce bandrol yönteminin uygulandığ 1 bölgelerde, ülkede tütün üretim, alım-satım, depolama, işletme ve ayrıca sigara imali ve satış aşamalarını Osmanlı devleti adına 30 sene boyunca gerçekleştirme yetkisi doğrultusunda kurulmuştur. (Demir, 2019: 424). 
Osmanlı Devleti'nin tütünden elde ettiği gelir Avrupalı alacaklıların dikkatini çekmiş, tütün üzerinde oluşturdukları 10 yıllık tekelle hem alacaklarını tahsil etmişler hem de Türk çiftçisini mağdur etmişlerdir.

Zamanla Duyun-u Umumiye Teşkilatı Osmanlı Maliye Teşkilatı'ndan daha fazla personele sahip bir kuruluş haline gelmiştir. Nitekim 1911 yılına gelindiğinde Osmanlı Devleti'nin Maliye Bakanlığının 5472 personeline karş1lık, Düyun-u Umumiye Konseyi'nin 8931 personeli bulunmaktaydı (Lewis, 1993: 447). Doğrudan doğruya yabancı alacaklıların denetiminde ve onlara karşı sorumlu olan Konsey, borçların ve borçların ödenmesine tahsis edilmiş devlet gelirlerinin yönetimini üzerine almıştı ve Türkiye milli gelirinin geniş bir bölümünü kontrol ediyordu (Lewis, 1993: 447).

Reji şirketinin planlaması çerçevesinde 1913-1918 arası beş yıllık dönemde yıllara göre tütün üretimi yıl sırasına göre, 53,31; 43,38; 13,87; 14,91; 17,01 ve 21,04 bin ton olarak gerçekleşmiştir (Toprak, 2017: 442).

Tütünün tek alıcısı konumunda olan Reji, üretilen tütünün fiyatlandırılması tekelini de kendi elinde bulundurmaktaydı. Üretim miktarının yanı sıra tütün fiyatını da belirlemesi çiftçi üzerinde büyük yük oluşturuyor, belirlenen fiyat çoğu zaman üreticiyi memnun etmiyordu. Bu durum emeğinin karş1lı̆gını alamayan üreticinin üretimden vazgeçerek bulunduğu resmi maili adı ile başlangıçta sadece ihracattan alınmak üzere memlekette geçimini temin edemediği için göç etmesini veya kaçakçılığa yönelmesini beraberinde getirmekteydi. Osmanlı'da tek tütün mamulleri üreticisi konumunda olan Reji, istediği ilde ve vilayette fabrika açma ve işletme ayrıcalığına sahipti. Reji şirketinin ayrıcalıkları arasında hangi çiftçilerin nereye ne kadar ekeceğini belirlemek, alım satım fiyatlarını belirlemek, Osmanlı Devleti'nin hangi bölgesine ne ölçekte fabrika açılacağına karar vermek, çalışacak personelleri ve işçileri belirlemek bulunmaktaydı. Reji şirketinin uygulamalarının üretici, tüketici ve işçileri memnun etmediği anlaşılmaktadır. "Reji, açtı̆̆ fabrikalarda genellikle ucuz emek gücü olan kadın ve çocukları kullanıyor, bilhassa işçinin emeğini sömürüyordu. Çalışma koşullarının kötü olması, çocukların neredeyse bedava denecek ücretlere çalıştırılması, Reji ile tütün fabrikası çalışanları arasında anlaşmazlıklar doğmasına neden olmuştur. Öyle ki Reji kurulmasından itibaren Osmanlı Devleti'nde Reji karşıtı grevler yapılmış, hatta kimi bölgeler silahlı çatışmalara tanıklık etmiştir. (Aydın, Kaya ve Karaçor, 2019: 24).

Reji, Osmanlı İmparatorluğu'nda faaliyette bulunduğu süre içerisinde başta tütün çiftçisi olmak üzere tütün işiyle uğraşan birçok kesimle sıkıntılar yaşamıştır. Reji'nin tütün çiftçisi/üreticisi ile yaşadığı çeşitli sıkıntılar şikâyet metinlerinde açıkça görülmektedir (Dığıroğlu, 2014: 236). Tütün üreticisinin Reji'yi şikâyet ettiği konular arasında ambar yapımı, ruhsatname sorunu, satın almalarda düşük fiyat verilmesi, muhammin tayininde şartname hükümlerine uyulmaması, şartnamede taahhüt edilen faizsiz kredinin verilmemesi ve kolluk görevinde kullandığı kolcuların tavırları yer almaktadır. Reji Şirketi’nin şikâyeti ise, üreticinin izinsiz tütün ziraatı yapması ve tütün kaçakçıllı̆ının önlenmesinde devlet memurlarının gerekli itinayı göstermemesidir (Dığıroğlu, 2014: 237).

Güran (2017: 312), 1887-1911 yılları arasında tütün eken çiftçi sayısını, tütün ekilen alanı ve dönüm başına verim oranını şu şekilde hesaplamıştır. Güran'a göre ortalama 128521 çiftçi tütün yetiştirmekte, ortalama 420278 dönüm arazide de tütün ekilmektedir. Ortalama üretim rekoltesi 84,765 ton, ortalama verimlilik ise, dönüm başına 82,73 kilogramdır. Keza, Güran (2017: 391), 1911 yılında tütünün toplam ithalattaki payının sadece \% 0,1, buna karşılık ihracattaki payının ise, \% 20.93 olduğunu belirtmektedir. İmparatorlukta üretilen tütünün büyük bir kısmı içeride tüketilmekle birlikte önemli ölçüde Avrupa'ya da ihraç edilmekteydi ve Selânik en büyük ihraç gümrüğü idi.

Rejinin yanlış uygulamaları sonucunda tütünün kaçak üretimi ortaya çıkmıştır. Kaçak üretime bağlı olarak Arka Sokak piyasası oluşmuş karaborsa fiyatları ortaya çıkmıştır. Reji Şirketi'nin kurulmasıyla birlikte şirketin öncelikli amacı kazancını artırmak olduğundan şirketin politikaları sonucu çiftçilerde hoşnutsuzluklar oluşmuş ve ülkede Reji ile çiftçiler arasında yaşanan sorunlar dönemin önemli bir sorunu olmuştur. Reji Şirketi'nin tütün ekimini kontrol etmek amacıyla sınırlama getirmesi, bazı bölgelerde tütün ekimin sonlandırmak istemesi ve düşük fiyat politika nedeniyle çiftçiler üretimlerini başka yollar aracılığıyla satmak zorunda kalmıştır. Bu da ülkede tütün kaçakçılığını ortaya çıkartmış ve kaçakçılık önemli faaliyet olarak ortaya çıkmıştır. Üreticiyi kaçağa sevkeden unsurların başında; Reji'nin satın alımlarda düşük fiyat vermesi, Reji'nin alımları zamanında gerçekleştirmemesi ve Reji’nin üreticiden ucuza aldığı tütünü kendilerine pahalı satması gelmektedir. Tüketiciyi kaçak tütüne yönelten sebepler ise Reji tütününün halka pahalı gelmesi ve Reji paketlerindeki tütünün kalitesinin düşük olmasıdır (Dığıroğlu, 2014: 259). Reji Şirketi kaçakçılıkla mücadele etmek için kurduğu kolculuk teşkilatı ile kaçaklığı engellemeye çalışmış ve bu kurum zamanla önemli sayıda kişiyi istihdam edecek yarı resmi bir kurum haline gelmiştir. Kolculuk teşkilatının kaçakçılıkla mücadele etmek için silah kullanma hakkını elde etmesiyle ülkede kolcu-kaçakçı arasında şiddetli çatışmalar yaşanmış ve kolculuk sistemi ülkede on binlerce insanın ölümüne neden olmuştur (Demir, 2019: 440). 


\section{ADANA TÜTÜN FABRİKASI}

Çok uluslu Reji Şirketine ait kütün fabrikalarından biri de Adana Tütün Fabrikasıdır. Fabrikanın devirteslim tutanağından, yaptığı İthalat ve ihracat miktarlarını görmek mümkündür. İthal ve ihraç edilen tütün ve bandrollerin miktarlarını da tutanakta görmekteyiz. Aynı tutanakta Adana tütün fabrikasının sahip olduğu alet edevat içinde havan, bıçak, defter, emirname ve ilmühaber sayılmıştır.

"Aslıoğlu Serakim ağanın Adana Külahçılarda 41 numrolu duhan fabrikasına 97 senesi şehri kanun-u evvel 17. gününde memur-u esbak Recep efendiden devrolunan ile 98 senesi şehri Mayıs 27 gününe değin mühren memuriyeti zarfinda vuku bulan yaprak duhan ile bandrollerin ithalat ve ihracatı balada muharrer olduğu üzere bi-t tenzil fabrikay-1 mezkur derununda mevcut bulunan yalnız 485 kıyye ${ }^{1}$ duhan ile 364 adet 200 dirhemlik 128 adet 100 dirhemlik 10269 adet 10 dirhemlik bininci nev bandroller ve 7 adet havan ve 87 adet biçak ve 8 kıt'a emirname ve 114 adet bandrol ilmühaberi ve bunların kaydına mahsus 3 kıt'a defter aynen ve kaydan mevcut olup devir-teslim kaidesi bi-l icra lahık sabık devri muhasebe defterleri üçer nüsha olarak bi-t tanzim taraflarımızdan temhir olup birer nüshası yedimizde hıfz olarak ve diğer bir nüshası canib-i müdüriyete takdim kılınmakla bu babdaki görülen muhasebede memur-u sabık mumaileyh fabrikaca bir güne zimmet edildiği olunduğuna havi işbu muhasebe defteri bi-t tanzim kılınmıştır 28 Mayıs 98" ( COA. ZB.304. 3. R. 31.03.1298). Osmanlı Arşivinde yer alan Adana Tütün Fabrikası'nın teslim tutanağı aşağıda tablolaştırılmıştır. (Tablo:1).

\footnotetext{
${ }^{1}$ Eskiden kullanılan bir ağırlık ölçüsü. Okka yahut Kıyye-i Atika da denir. Günümüzdeki 1282 grama eşittir.1 Kıyye=400 Dirhem (s.z.)
} 
Tablo 1: Adana Tütün Fabrikası Teslim Tutanağı

\begin{tabular}{|c|c|c|c|c|c|c|c|c|c|c|c|c|c|c|}
\hline \multicolumn{5}{|c|}{ İHRACAT } & \multicolumn{5}{|c|}{ İTHALAT } & \multicolumn{5}{|c|}{ FABRIKKADA MEVCUT ALAT VE EDEVAT } \\
\hline \multirow{2}{*}{\multicolumn{2}{|c|}{ DUHAN ( kıyye ) }} & \multicolumn{3}{|c|}{ BANDROL NEVİ VE ADETLERİ } & \multirow{2}{*}{\multicolumn{2}{|c|}{ DUHAN (k1yye) }} & \multicolumn{3}{|c|}{ BANDROL NEVİ VE ADETLERİ } & \multirow{3}{*}{\begin{tabular}{|l|} 
HAVAN \\
7 \\
\end{tabular}} & \multirow{3}{*}{\begin{tabular}{|l} 
BIÇAK \\
87 \\
\end{tabular}} & \multirow{3}{*}{\begin{tabular}{|l} 
DEFTER \\
3 \\
\end{tabular}} & \multirow{3}{*}{\begin{tabular}{|l} 
EMİRNAME \\
8 \\
\end{tabular}} & \multirow{3}{*}{\begin{tabular}{|l} 
İLMUHABER \\
86 \\
\end{tabular}} \\
\hline & & 200 kiyye & 100 kiyye & 10 kiyye & & & \multirow{2}{*}{\begin{tabular}{|l|}
200 kiyye \\
399 \\
\end{tabular}} & \multirow{2}{*}{$\begin{array}{l}100 \text { k1yye } \\
146 \\
\end{array}$} & \multirow{2}{*}{\begin{tabular}{|l|}
10 kiyye \\
19903 \\
\end{tabular}} & & & & & \\
\hline- & - & - & - & - & - & 962 & & & & & & & & \\
\hline- & 508 & - & 66 & 29820 & - & 547 & - & - & 30609 & - & - & - & - & 3 \\
\hline- & 800 & - & 12 & 47880 & - & 893 & - & - & 40812 & - & - & - & - & 4 \\
\hline- & 702 & 15 & 30 & 41520 & - & - & - & - & 40812 & - & - & - & - & 4 \\
\hline- & 923 & 3 & 66 & 54660 & - & 637 & - & 112 & 51015 & - & - & - & - & 5 \\
\hline- & 1052 & - & 55 & 62580 & - & 1316 & - & - & 61218 & - & - & - & - & 6 \\
\hline- & 1168 & 15 & 84 & 68940 & - & 1217 & - & 182 & 71421 & - & - & - & - & 7 \\
\hline- & - & - & - & - & - & 66 & - & - & - & - & - & - & - & - \\
\hline- & 5163 & 33 & 312 & 305400 & - & 5638 & 399 & 440 & 315790 & 7 & 87 & 3 & 8 & 114 \\
\hline- & & & & & & 5153 & 33 & 312 & 305400 & - & - & - & - & - \\
\hline- & & & & & & 485 & 366 & 128 & 10390 & - & - & 3 & 8 & 114 \\
\hline & & & & & & - & 2 & - & 121 & - & - & - & - & - \\
\hline- & & & & & & 485 & 364 & 128 & 10269 & 7 & 87 & 3 & 8 & \\
\hline
\end{tabular}


Tablo 1 deki verilere göre ithal edilen duhan(tütün ) miktarı 5638 kıyye (7228 kg)'dir. Bu miktarın \% 91.57'si ( 5153 kıyye=6606 kg) ihraç edilmiştir. Fabrikada mevcut olan tütün miktarı ise 485 kıyyedir ( 621,77 $\mathrm{kg}$ ). Yine aynı tabloya göre 200 kıyyelik bandrollerden 399 adet, 100 kıyyelik olan bandrollerden 440 adet,10 kıyyelik olan bandrollerden ise 315790 adet bandrol ithal edilmiştir. İthal edilen bandroller den 200 kıyyelik olanlardan 33 adet, 100 kiyyelik olan bandrollerden 312 adet ve 10 kiyyelik olan bandrollerden ise 305400'ü ihraç edilmiştir. XIX. yüzyılın ilk yarısında ihracat, Fransız İhtilâli'nin ardından Avrupa'daki siyasî gelişmelerle XVIII. yüzyılın sonlarında Avrupa tütün üretimindeki artış yanında Amerikan tütünü gibi dış, Mora ayaklanması ve Kavalalı Mehmed Ali Paşa isyanı gibi iç sebeplere bağlı olarak düşüş gösterdi. 1861'de vergi alınmaması yanında Amerika iç savaşı yüzünden ihracatta patlama oldu. 1878 yılına gelindiğinde Mısır'a yollananlar dahil olmak üzere bu miktar 10 milyon okkaya çıktı ve imparatorluğun sonuna kadar 7-10 milyon okka seviyesinde seyretti (Y1lmaz, 2012: 3).

Adana tütün fabrikasının personeli ve istihdam ettiği işçiler ile ilgili bilgilere ulaşılamamıştır. Ancak Samsun tütün fabrikasında çalışan işçilerin miktar ve özellikleri aşağıdaki gibidir.

Tablo 2: 1914'te Samsun Reji Fabrikasında Çalışan İşçi Sayısı

\begin{tabular}{|c|c|c|c|}
\hline Çalıştığı Daire & Toplam & Kadın & Erkek \\
\hline Sigara Dairesi & 100 & 84 & 16 \\
\hline Harman Dairesi & 127 & 109 & 18 \\
\hline Paket Dairesi & 81 & 52(küçük k1z) & 29 \\
\hline Kutu Dairesi & 19 & 19 & \\
\hline Ambalaj Dairesi & 4 & 1 & 3 \\
\hline Hıdmet-i Dahiliye & 10 & & 10 \\
\hline Kıyhane Dairesi & 30 & & 30 \\
\hline TOPLAM & 371 & 265 & 103 \\
\hline
\end{tabular}

Çalışan işçilerin \% 71.42 si kadındır. Kadın işçilerin \% 64.19’u küçük kızdır. Bu verilerden hareketle sektörde kadın ve çocuk işçilerin tercih edildiğini söyleyebiliriz. Kadın işçiler el becerisi için tercih edilmiş olsa bile, çocukların tercih edilme nedeninin düşük ücret olduğu düşünülebilir.

\section{SONUÇ}

Günümüzde pek çok kanser türünün ana sebebi olarak gösterilen tütün, Amerika kıtasının keşfini müteakiben geldiği Avrupa'da oldukça muteberdi. Zira pek çok hastalığa iyi geldiği ve keyif verici olduğu gibi referansları vardı. Her türlü hastalığa iyi geldiği fikri Avrupa'da hızla yayılırken, tütün kısa sürede tanınmaya başlanmış, ilk olarak İspanya'da daha sonra tüm dünyada kullanımı yaygınlaşmıştır. İlk başlarda süs bitkisi ve şifa amacıyla kullanılan tütün bitkisi veba hastalığının ortaya çıkmasıyla kullanımı artmıştır. Daha sonra keyif verici madde olarak da kullanılması, tütünün yaygınlaşması ve bir kültür haline gelmesi çokta uzun sürmemiş̧ir.

1854 yılında Kırım harbi nedeniyle ilk defa borca giren Osmanlı Devleti takip eden yıllarda defalarca borçlandı. İlk borçlanmadan 20 yıl sonra borçları değil, faizlerini dahi ödeyemez duruma düşmüştü Düyun-u Umumiye Komisyonu borçlarını tahsil etmeye gelirken Osmanlı Maliye Teşkilatı ndan daha fazla personelle geldi. Anlaşmanın ağır şartlarını kendisi koydu. Reji Şirketi de bunun bir parçasıydı. "Reji'nin kurulmasıyla ülkede tütün ziraatının gerilediği, Reji'nin politikaları nedeniyle ortaya çıkan kaçakçılıkla mücadele adı altında on binlerce Osmanlı vatandaşının öldüğü ve birçok bölgede çiftçilerin tütün ekimini bıraktıkları hatta yabancı ülkelere göç ettikleri yazılmıştır.

Reji Şirketi tütünün üretimi tüketimi ve pazarlanması konusunda sahip olduğu imtiyazlarla borç tahsilatından daha fazla şeyler yapmıştır. Tekel gücünü kötüye kullanmış, tütün kaçakçılığı ile mücadele çerçevesinde oluşturduğu sabıkalılardan oluşan kolluk gücüyle pek çok cinayet işlemiştir. Ayrıca istihdam konusunda da Osmanlı Devleti ile değil kendi mensup olduğu ülkeye fayda sağlamıştır "Reji İdaresi tütün fabrikalarında halkın emeğini sömürürken, idarenin üst yönetim kademelerinde halktan çalışan bulundurmamış genellikle kendi yandaşlarından ülke vatandaşlarına istihdam sağlamıştır. Samsun ili Reji Nezareti örneğinden görüleceği gibi Reji Kurumu'nun yönetici kadrosunu ağırlıklı olarak yabancı ülke vatandaşları oluşturmuştur. (Aydın, Kaya ve Karaçor,2019: 25 ). 
Fabrikalarda tütünün işlenerek mamül hale getirilmesinden sonraki tüketiciye ulaşıncaya kadar geçen süreç de belirli kurallara bağlanmıştı. Kıyılmış tütünlerin, üzerine bandrol yapıştırılmış 0,5 okka, 100, 50, 20 ve 10 dirhemlik standart paketlere veya kaplar içine konmadan açık olarak fabrika dışına çıkartılması yasaktı. Tütünler, fiyatlarına göre 5 gruba ayrılarak, birinci cins tütünün kıyyesinden 30, ikincisinden 20, üçüncüsünden 15, dördüncüsünden 10 ve beşincisinin kıyyesinden 5 kuruş olmak üzere farklı oranlarda sarfiyat resmi alınacak ve her cinsin vergi bandrolü ayrı ayrı renklerde olacaktı (Yılmaz, 2005:146).

Reji Şirketi kaçakçılıkla mücadele etmek için kurduğu kolculuk teşkilatı ile kaçaklığı engellemeye çalışmış ve bu kurum zamanla önemli sayıda kişiyi istihdam edecek yarı resmi bir kurum haline gelmiştir. Kolculuk teşkilatının kaçakçılıkla mücadele etmek için silah kullanma hakkını elde etmesiyle ülkede kolcu-kaçakçı arasında şiddetli çatışmalar yaşanmış ve kolculuk sistemi ülkede on binlerce insanın ölümüne neden olmuştur.

Reji şirketi karını maksimize etmek için yaptığı kötü uygulamalarla kaçakçılık ve benzeri olumsuz durumların yaşanmasına neden olmuştur. Reji şirketi karını maksimize ederken üreticiyi mağdur etmiş Devleti vergi kaybına uğratmıştır. Reji Şirketi'nin uygulamaları, Osmanlı Devleti'nin ya da çiftçisinin menfaatlerini değil, kendi karını maksimize etmeyi amaçlıyordu. Bunun sonucunda kısa süre sonra de büyük anlaşmazlıkların çıkmasına sebep olmuştur. Reji Şirketi'nin tütün ekimini kısıtlaması, düşük fiyat belirlemesi, depo yetersizliği ve çiftçilere karşı kötü muamele etmesi kaçakçılık vb. olayların yaşanmasına yol açmıştır.

Tütün kaçakçılığı ağırlıklı olarak karadan yapılmakta, ancak denizde de kaçakçılık hadiselerine sıkça rastlanmaktadır. Denizden yapılan kaçakçılığı önlemek üzere Reji faaliyete başladığı ilk yıllardan beri çeşitli önlemler almıştır. Selanik ve Aydın vilayetleri gibi denize kıyısı olan vilayetlerde görev yapmak üzere “tarassud kayıkları” görevlendirmiş, kaçakçılıkla mücadele etmiştir (Dığıroğlu, 2014: 261).

Sonuç itibarıyla Osmanlı Devleti borçlanarak savaşları finanse etmiş ama yıkılmasının nedenlerinden birini oluşturmuştur. Zira alacak tahsili için gelenlerin aşırı istihdamı, istihdamı kendi ülkesinden yapması, tütün üreticilerinin mağduriyeti vb. alacaklıların alacak tahsilinden daha fazla şey yaptıklarını göstermektedir.

Adana Tütün Fabrikası'nın tütünü hem ithal ettiği hem işleyerek ihraç ettiği anlaşılmaktadır. Sahip olduğu havan ve bıçaklardan hareketle ithal edilen tütünün işlendiğini söylemek mümkün gözükmektedir. Mamul hale getirilen tütünler ihraç edilmekteydi. Fabrika devir-teslim tutanağında görüldüğü gibi ithal edilen tütünün \% 91.57 si ihraç edilmiştir, henüz satılmayan kısmı ise stoktadır. İç piyasadan mal (tütün ) alındığına ya da satıldığına dair bir ibare görülmemektedir. Fabrikanın ticari faaliyetlerinin dış piyasaya dönük olduğu anlaşılmaktadır. 


\section{KAYNAKÇA}

Akgündüz, A. \& Öztürk, S. (2000). Bilinmeyen Osmanlı. OSAV, İstanbul.

Aydın, M., Kaya, P. H. \& Karaçor, Z. (2019). Osmanlı İmparatorluğu'nda Özelleştirme Faaliyetlerine Örnek Olarak Reji Tütün İdaresi. Niğde Ömer Halisdemir Üniversitesi Sosyal Bilimler Enstitüsü Dergisi, 1(3), 18-28.

Çadırcı, M. (1997). Tanzimat Döneminde Anadolu Kentlerinin Sosyal ve Ekonomik Yapısı, TTK Yayınları, Ankara.

Demir, K. (2019). Meşrutiyet Dönemi Osmanlı Basınında Tütün Tarımı Ve Reji Şirketi. Balıkesir University The Journal of Social Sciences Institute, 22(41), 419-445.

Dığıroğlu, F. (2014). Selanik Ekonomisinde Unutulmuş Bir Alan: Tütün Üretimi, Ticareti ve Reji (1883-1912), Osmanlı Araştırmaları, 11(3), 227-272.

Genç, M. (2010). Osmanlı İmparatorluğu'nda Devlet ve Ekonomi, Ötüken Yay., İstanbul.

Güran, T. (2017). Resmi İstatistiklere Göre Osmanlı Toplum ve Ekonomisi, İş Bankası Kültür Yayınları, İstanbul.

İnalcık, H. (2000). Osmanlı İmparatorluğunun Ekonomik ve Sosyal Tarihi, Cilt 1-2, Eren Yayınları, İstanbul.

Kazgan, G. (1999). Tanzimat’tan XXI. Yüzyıla Türkiye Ekonomisi Altın Kitaplar Yayınevi, İstanbul.

Kütükoğlu, M. (2013). Balta Limanı’na Giden Yol Osmanl1-İngiliz İktisadi Münasebetleri (1580-1850), TTK, Ankara.

Lewis, B. (1993). Modern Türkiye'nin Doğuşu, (Çev. Metin Kıratlı), TTK Yay., Ankara.

Osmanlı Arşivi; ( COA. Y. PRK: AZJ.6-60.), ( COA.İ..DUİT_97-1_11_54_01), ( COA. ZB.304. 3. R. 31.03.1298), ( COA. İ..DUIT_00091686.380).

Pamuk, Ş. (2014). Türkiye'nin 200 Yıllık İktisadî Tarihi, İş Bankası Kültür Yay., İstanbul.

Seyidoğulları, M. (2009). Tütün ve Tütün Kontrolü, Türk Toraks Derneği, Ankara.

Toprak, Z. (2017). Türkiye'de Milli İktisat 1908-1918, Doğan Kitap, İstanbul.

Yılmaz, F. (2005). Osmanlı İmparatorluğunda Tütün: Sosyal, Siyasi ve Ekonomik Tahlili (1600-1883), Marmara Üniversitesi Türkiyat Araştırmaları Enstitüsü, Türk Tarihi Anabilim Dalı Yakınçağ Tarihi Bilim Dalı, Doktora Tezi, İstanbul.

Yılmaz, F. (2012). Tütün, TDV İslâm Ansiklopedisi, C. 42. İstanbul, 1-4. 


\section{EKLER: OSMANLI ARȘIV BELGELERİ}

\section{Ek 1- Kanun}
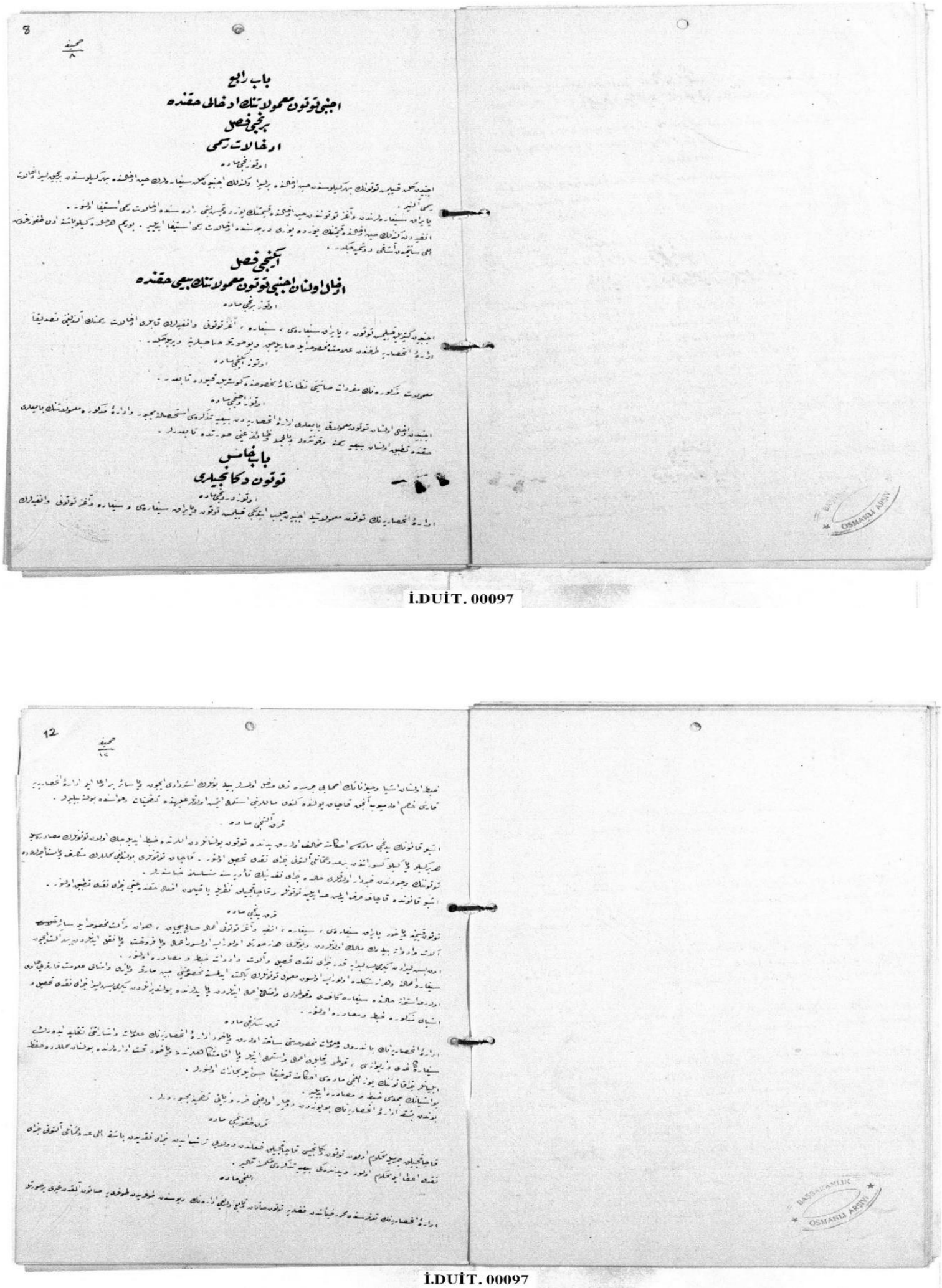
Ek 2- Tütün Fabrikası Teslim Tutanağı

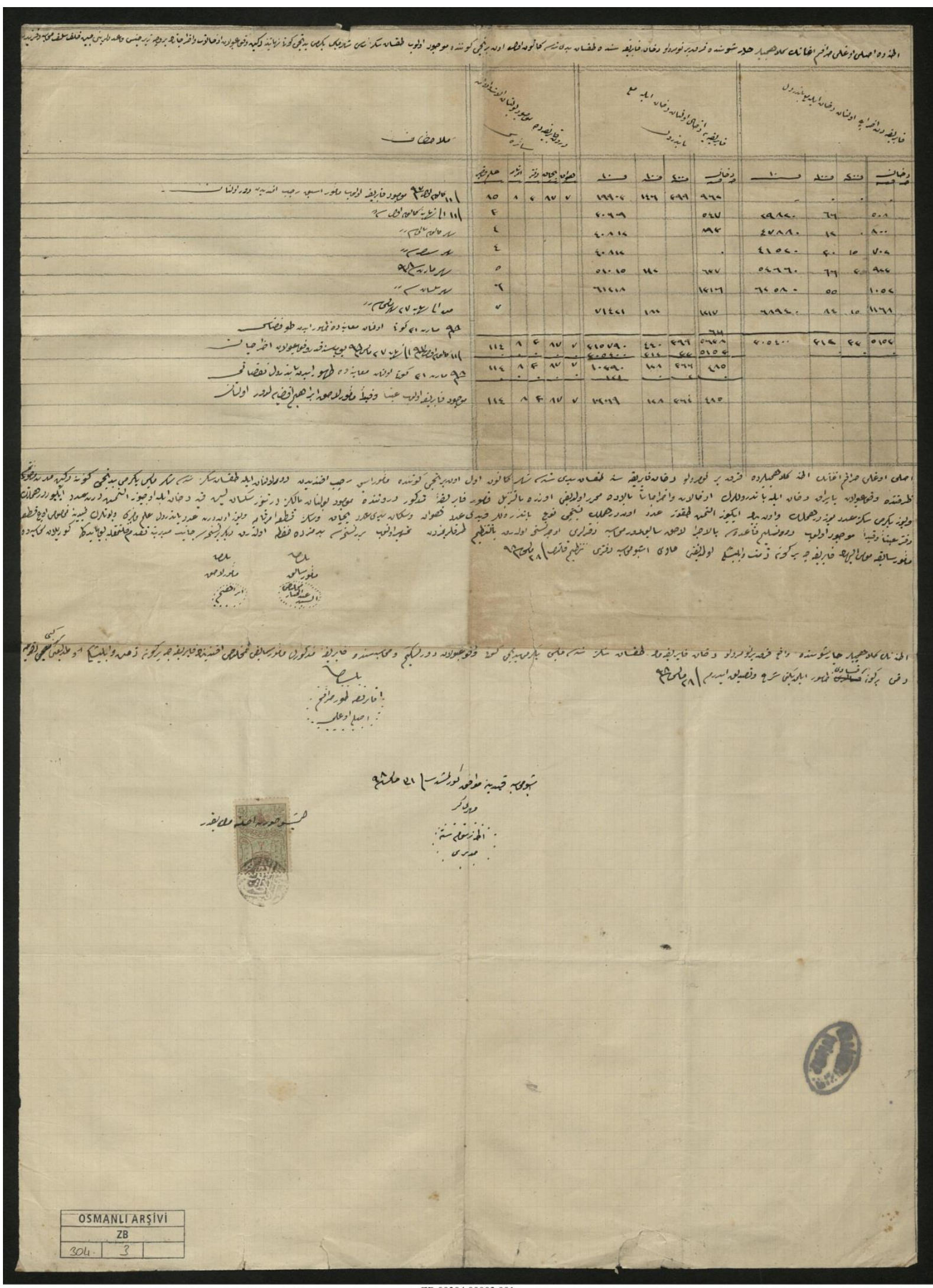

ZB.00304.00003.001 